\title{
The biodiversity and species composition of the spider community of Marion Island, a recent survey (Arachnida: Araneae)
}

\author{
T.T. KhOZA, S.M. DipPEnAAR and A.S. DipPENAAR-SchoEMAN
}

Khoza, T.T., S.M. Dippenaar and A.S. Dippenaar-Schoeman. 2005. The biodiversity and species composition of the spider community of Marion Island, a recent survey (Arachnida: Araneae). Koedoe 48(2): 103-107. Pretoria. ISSN 0075-6458.

\begin{abstract}
Marion Island, the larger of the Prince Edward Islands, lies in the sub-Antarctic biogeographic region in the southern Indian Ocean. From previous surveys, four spider species are known from Marion. The last survey was undertaken in 1968. During this study a survey was undertaken over a period of four weeks on the island to determine the present spider diversity and to record information about the habitat preferences and general behaviour of the species present. Three collection methods (active search, Tullgren funnels and pitfall traps) were used, and spiders were sampled from six habitat sites. A total of 430 spiders represented by four families were collected, Myro kerguelenesis crozetensis Enderlein, 1909 and M. paucispinosus Berland, 1947 (Desidae), Prinerigone vagans (Audouin, 1826) (Linyphiidae), Cheiracanthium furculatum Karsch, 1879 (Miturgidae) and an immature Salticidae. The miturgid and salticid are first records. Neomaso antarticus (Hickman, 1939) (Linyphiidae) was absent from samples, confirming that the species might have been an erroneous record.
\end{abstract}

Key words: Araneae, biodiversity, Desidae, Linyphiidae, Marion Island, Miturgidae, Salticidae, spiders.

T.T. Khoza \& S.M. Dippenaar, School of Molecular and Life Sciences, University of Limpopo, Private Bag X1106, Sovenga, 0727 Republic of South Africa; A.S. DippenaarSchoeman, ARC-Plant Protection Research Institute, Private Bag X134, Queenswood, 0121 Republic of South Africa/ Department of Zoology and Entomology, University of Pretoria, Republic of South Africa.

\section{Introduction}

The Prince Edward Island Group has a surprising number of terrestrial invertebrates. Most species are specially adapted to survive in the harsh conditions. The islands remained largely pristine, except for Marion Island. Increased human activities led to a number of introduced species being documented. From Marion, two arachnid orders have been recorded: Acari (mites) represented by 60 species (Van Pletzen \& Kok 1971; Hänel \& Chown 1998), and Araneae (spiders) represented by four species (Lawrence 1971).

The first two spider species reported from Marion Island were Myro paucispinosus Berland, 1947 (Desidae) and Porrhomma antartica Hickman, 1939 (now Neomaso antarticus) (Linyphiidae) (Berland 1947). During a South African expedition in 1968, a further two species, Myro kerguelenensis O.P.-Cambridge, 1876 and Erigone vagans Audouin, 1826 (now Prinerigone vagans), were added to the list (Lawrence 1971). Ledoux (1991), in his revision of the spiders of the French Sub-Antarctic Islands (Crozet and Kerguelen), a group of islands some $950 \mathrm{~km}$ east of Marion Island, discussed the Marion Island spiders as well. He transferred Porrhomma antartica to Neomaso antarticus and recognised two subspecies of $M$. kerguelenensis, namely M. kerguelenensis crozetensis (the subspecies recorded from Marion, Prince Edward and Crozet Islands), and $M$. kerguelenensis kerguelenensis O.P.-Cambridge, 1876 that occurs only on Kerguelen Island. The only other reference to spiders of the Southern Ocean islands was by Pugh (2004), who indicated the occurrence of Neomaso antarticus from the Prince Edward 
Islands as a "problem entry", as it is based only on published reports (Berland 1947) and has never been collected again.

During this study a survey was undertaken over a period of four weeks (11 April - 30 May 2004) on the island to determine the latest spider diversity and to record their habitat preference, with notes on their general behaviour.

\section{Study area}

The Southern Ocean, stretching from the coast of Antarctica to the Antarctic Polar Frontal Zone, contains several isolated groups of islands. The Prince Edward Island Group lies in the southern Indian Ocean and consists of two islands, Prince Edward Island and Marion Island, separated by about $19 \mathrm{~km}$ of water. Prince Edward is uninhabited, while Marion, the larger of the Prince Edward Island Group, is home to weather and research stations manned year-round, and is managed by South Africa as a Special Nature Reserve. Marion Island is $1770 \mathrm{~km}$ southeast of Port Elizabeth and a little further from Antarctica. This island originated through volcanic eruptions and is only about 500000 years old. It is one of the peaks of a coalescing shield volcano and is about $1300 \mathrm{~m}$ above sea level.

Mean monthly air temperature of the island closely follows that of the ocean and ranges from $3.6^{\circ} \mathrm{C}$ (August) to $7.9^{\circ} \mathrm{C}$ (February). Sunshine averages $3.6 \mathrm{hrs}$ per day. Rain occurs on average 317 days per year, more frequently in winter, with a yearly average of $2500 \mathrm{~mm}$. Snow and frost may occur in any month of the year, with snow on average about 80 days per year. Northwesterly winds are predominant, frequently reaching gale force $(>55 \mathrm{~km} / \mathrm{h})$ and occur about 107 days of the year. The climate can therefore be summarised as cold, wet and windy (http://marion.sanap.org.za/weather. html). There are relatively few influencing factors beyond its maritime climate (Joubert 2004). The island consists of a watery terrain with little vegetation and the absence of trees is largely due to the persistent strong westerly winds (http://www.btintorner). Vegetation consists mainly of about 187 species of flowering plants, ferns, lichens, mosses, grasses and liverworts (http://cbp.inxcom.com).

\section{Methods}

Spiders were collected at Marion Island $\left(46^{\circ} 54^{\prime} \mathrm{S}\right.$, $37^{\circ} 50^{\prime} \mathrm{E}$ ) over a period of four weeks (11 April - 30 May 2004) from six different sites. Collecting took place within approximately a $2-\mathrm{km}$ radius of the research station that is situated on the northeastern side of the island. The description of the sites are as follows: Skua Ridge - a rocky, barren fell field area with only a few plants consisting mostly of Azorella selago Hook.fil.; Tafelberg - similar to Skua Ridge but with more densely vegetated patches and at a higher altitude; Ship's Cove - an area with bare patches and areas covered with tussock grass $\mathrm{Poa}$ cookii Hook.f. and Alpine water fern Blechnum penna-marina $\mathrm{H}$.Christ with some areas exposed to salt spray from the sea; Research Station - a mire covered with a mixture of B. penna-marina, Agrostis magellanica Lam., Acaena magellanica Vahl and Uncinia compacta R.Br., as well as patches of Cotula plumosa Hook.f. and B. penna-marina; an area between Research Station and Trypot Beach (RSTB) - covered with $B$. penna-marina; Trypot Beach - an area similar to Ship's Cove covered with $B$. penna-marina, C. plumosa and P. cookii (Hänel \& Chown 1998).

Three different collecting methods (Eardley \& Dippenaar 1996) were used to catch spiders from the different areas. Pitfall trapping $(50 \mathrm{ml}$ containers, $5.5 \mathrm{~cm}$ height $\times 3.7 \mathrm{~cm}$ diameter) half-filled with $70 \%$ ethanol (EtOH) and buried into the ground with the upper rim level with the ground surface was conducted at the Trypot Beach and Research Station sites. The first set of pitfall traps at both locations was buried in exposed areas with less Cotula growth with five traps in one row, placed one metre apart. The second set of traps at the Research Station site was buried in thicker growth of Cotula, while that at the Trypot Beach site was planted at the edge of the sea exposed to salt spray. The pitfall traps at Research Station were kept open during the whole sampling period and were checked and emptied daily. Those at Trypot Beach were kept open for a period of five days and were also checked and emptied daily. Spiders were caught by actively searching through the sample sites. Active searching was done at Tafelberg (both in densely vegetated patches and on gray lava), Skua Ridge (on both Azorella selago 
cushions and rocks) and Ship's Cove Beach (in both $P$. cookii and B. penna-marina areas). Active searching was done daily on a single sample site. Plant material (Agrostis castellana Boiss. \& Reut., A. stolonifera L., Sononia sp. and B. penna-marina) was collected from Research Station and RS-TB and put into ten Tullgren funnels. The Tullgren funnels were operated for two weeks. They were checked every morning to remove old plant material while new material was added late in the afternoon. Old material was checked before being discarding, and spiders stuck in the plant material were collected by hand.

Collected spiders were preserved in $70 \%$ ethanol and studied using stereo and light microscopes. Voucher specimens are housed in the National Collection of Arachnida, at the ARC-Plant Protection Research Institute in Pretoria.

\section{Results and discussion}

A total of 430 individuals represented by four families and four species were collected. These included: Myro kerguelenesis crozetensis and M. paucisipinosus (Desidae); Prinerigone vagans (Linyphiidae), as well as a new record Cheiracanthium furculatum (Miturgidae) and an immature Salticidae, which could unfortunately not be identified to species level (Table 1).

Prinerigone vagans: These are very small brown spiders with a shiny reddish tint. The males are easily recognised by the row of large tubercles on the anterior surface of the chelicerae and the large apophysis on the femur of the palp. Their size ranges from

Table 1

Number of spiders of each species collected from Marion Island during April and May 2004, with locations from which they were collected and method of collection.

$(\mathrm{Imm}=$ immatures, $\mathrm{As}=$ active searching, $\mathrm{Pt}=$ pitfall trapping, $\mathrm{Tf}=$ Tullgren funnel $)$

\begin{tabular}{llrrrrr}
\hline Spider species & Location & Method & Male & Female & Imm & Total \\
\hline Linyphiidae & & & & & \\
Prinerigone vagans & Trypot Beach & Pt & 6 & 16 & 9 & 31 \\
& Ship's Cove & As & 55 & 49 & 10 & 114 \\
Total & Research Station & Pt, Tf & 2 & 11 & 9 & 22 \\
& & & 63 & 76 & 28 & 167 \\
\hline Desidae & & & & & \\
Myro paucispinosus & Trypot Beach & Tf, As & 0 & 1 & 2 & 3 \\
& Tafelberg & As & 0 & 0 & 6 & 6 \\
& Research Station & Pt, Tf & 0 & 0 & 3 & 3 \\
Total & Skua Ridge & As & 0 & 0 & 6 & 6 \\
\hline Myro kerguelenesis crozetensis & Trypot Beach & Tf, As, Pt & 1 & 7 & 6 & 14 \\
& Ship's Cove & As & 0 & 0 & 2 & 2 \\
& Tafelberg & As & 5 & 3 & 35 & 43 \\
& Research Station & Pt, Tf & 10 & 4 & 64 & 78 \\
Total & Skua Ridge & As & 47 & 9 & 50 & 106 \\
\hline Salticidae & & & 63 & 23 & 157 & 243 \\
Miturgidae & Tafelberg & As & 0 & 0 & 1 & 1 \\
Cheiracanthium furculatum & Skua Ridge & As & 1 & 0 & 0 & 1 \\
\hline TOTAL & & & 127 & 100 & 203 & 430 \\
\hline
\end{tabular}


1.3-1.5 mm. A total of 167 specimens were collected comprising of 76 females, 63 males and 28 immatures. They were collected from three of the six locations with all three collecting methods (Table 1). Pitfall trapping was the least successful, since they spin a web on the upper rim of the pitfall traps. In patches of $P$. cookii, they occurred in clusters with more than a hundred individuals per cluster. A group of spiders was found at the base of the plant with the delicate sheet webs on top of the grass blades. Most specimens caught in C. plumosa patches were collected from disturbed areas occupied by penguins and seals. Here the spiders were mostly single and did not form clusters as in the $P$. cookii patches. Prinerigione vagans is an Old World species with a wide distribution (Platnick 2005). This species is frequently found in disturbed habitats and was introduced by man onto the island.

Of the two Myro species, M. paucisipinosus is less common on Marion and only 18 specimens were collected, represented by one adult female and five immature females, two immature males, while the rest were immature. This species can be distinguished by its larger size (10-12 $\mathrm{mm})$, darker colour and especially the presence of fur-like setae on the legs and body. Ledoux (1991) provided illustrations of both the male and female genitalia. Myro paucisipinosus specimens were collected mainly by hand and with the Tullgren funnels from four of the six study sites (Table 1). It was absent from Ship's Cove. This species is known from Marion and Crozet (Lawrence 1971; Platnick 2005) and Prince Edward Islands (Lawrence 1971). Myro paucispinosus was previously collected from under rocks, and are more common at high altitudes (Lawrence 1971). In this study they were mainly collected by active searching and were always found in rocky areas next to cushions of Azorella selago at higher altitudes. The egg sac found with the mature female was attached to the under side of rocks and camouflaged with dirt (Lawrence 1971).

Myro kerguelenesis crozetensis is more abundant and a total of 243 specimens were collected represented by 63 females, 23 males and 157 immatures. They have been collected from five of the six sites but were most abundant at Skua Ridge (106 specimens), Research Station (78), Tafelberg (43) and Trypot Beach (14) (Table 1). Only two immature specimens were collected from Ship's Cove. They occur sympatrically with M. paucisipinosus and have been collected from the same pit traps. Myro k. crozetensis is smaller $(4.9-5.5 \mathrm{~mm})$ than $M$. paucisipinosus and more yellowish in colour without the fur-like setae on the legs and body. IIlustrations of the genitalia are provided by Ledoux (1991). During this study they were mostly caught from under rocks at lower altitudes by active searching and less frequently with pitfall trapping. Immature males were mostly caught by Tullgren funnels from Blechnum penna-marina and Agrostis stolonifera. No webs were observed, only egg sacs (smaller than that of $M$. paucispinosus) on the ground camouflaged with brownish stripes.

Cheiracanthium furculatum: One male specimen was collected by hand from Skua Ridge. The species can be recognised by the creamish-yellow body with the ocular area and mouthparts black-brown; male palp distinctive in having both the cymbial apophysis and retrotibial apophysis long and sharply pointed (Lotz 1995). This species is commonly found throughout the southern African region as well as from the Cape Verde Islands, Gabon, Rwanda, Tanzania and Zaire (Lotz 1995). It is synanthropic and commonly found in houses in South Africa where they are also responsible for most of the cytotoxic spider bites (Newlands 1975).

The immature specimen of the family Salticidae was found at Tafelberg under rocks. The genitalia are very important in species identification and unfortunately it could not be identified (Wesolowska pers. comm.). No specimens of Neomaso antarticus were collected. 


\section{Conclusion}

During the survey conducted in 1968 a total of 71 specimens were collected from two families (Desidae and Linyphiidae). During the current survey a total of 430 individuals from four families were collected. Spiders were collected from five of the six sampling sites with no spiders found in RS-TB where the only collecting method used was Tullgren funnels. This study confirms the observation of Plugh (2004) that Neomaso antarticus was wrongly reported to occur on Marion Island. Further surveys are needed to locate adult specimens of the salticid species collected during this study to determine its identity. The distribution of Cheiracanthium furculatum, a synantropic species that is of medical importance, also needs to be monitored

\section{Acknowledgements}

The authors thank Mr R Mecer (The Capacity Building Program for Climate Change Research (CBPCCR)) for field assistance and advice and both Stellenbosch University and the Stellenbosch University/DEAT/USAID CBP-CCR for sponsoring the study and the provision of a student bursary and Dr Wanda Wesolowska of the Wroclaw University for the assistance with the salticid identification.

\section{References}

Berland, L. 1947. Croisière du Bougainville aux iles australes françaises. Memoirs of the Museum of Natural History, Paris 20: 53-64.
EARDLEy, C.D. \& A.S. DipPenaAR-Schoeman. 1996. Collection and preparation of material. I. Collecting methods. Pp: 23-35. In: UYs, V.M. \& R.P. URBAN (eds). How to collect and preserve insects and arachnids. Plant Protection Research Institute, Handbook 7. Pretoria: Agricultural Research Council.

HÄNel, C. \& S.L. Chown. (1999). An Introductory Guide to the Marion and Prince Edward Island Special Nature Reserves. Fifty Years After Annexation. Pretoria: Department of Environmental Affairs \& Tourism.

JOUBERT L. 2004. Love and desolation in the land of Foo. Getaway 15: 105 - 109.

LaWrence R.F. 1971. Araneida. Pp. 301-313. In: VAN ZINDEREN BAKKER, E.M., J.M. WINTERBOTTOM \& R.A DYer (eds.). Marion and Prince Edward Island: report on the South African biological and geological expedition 1965-1966. Cape Town: A.A. Balkema.

Ledoux, J. -C. 1991. Araignées des îles subantarctiques françaises (Crozet et Kerguelen). Revue Arachnologique 9: 119-164.

Lotz, L.N. 1995. The genus Cheiracanthium (Araneae: Clubionidae) in Southern Africa. MSc thesis, University of the Free State, Bloemfontein.

NEwLANDS, G. 1975. Review of the medically important spiders of southern Africa. South African Medical Journal 49: 823-826.

Platnick, N.I. 2005 The World Spider Catalog, Version 5.5. (http://research.amnh.org/entomology/spiders/catalog.

Pugh, P.J.A. 2004. Biogeography of spiders (Araneae: Arachnida) on the islands of the Southern Ocean. Journal of Natural History 38: 1461-1487.

Van Pletzen, R. \& D.J. KoK. 1971. Oribatei. Pp. 314-318. In: VAN ZINDEREN BAKKER, E.M., J.M Winterbottom \& R.A. Dyer (eds.). Marion and Prince Edward Island: report on the South African biological and geological expedition 1965-1966. Cape Town: Balkema. 